\title{
Supporting the Academic Aspirations of Indigenous College Students Through Youth Camps: Qualitative Evidences From the Philippines
}

\author{
Arlan E. Dela Cruz \\ Holy Angel University \\ Angeles City, Philippines \\ School of Arts \& Sciences \\ Pampanga, Philippines
}

\begin{abstract}
Indigenous Students, By Comparison To Nonindigenous Students In The Same Countries, Are Suffering From Lower Enrolment Rates, Higher Dropout Rates And Poorer Educational Outcomes On A Global Scale. As A Response, In 2015, A Higher Education Institution Located In Central Luzon, Philippines Extended Support To The Indigenous Youth Pursuing College Studies Through Providing Youth Camp Program. This Qualitative Descriptive Study Evaluated The Extent Bywhich Indigenous Youth Camp Program Experience Has Supported The Academic Goals Of The Indigenous Aeta Camp Participants As Well As Contributed To Their Overall WellBeing. Thematic Analysis Results Revealed Three Major Findings: A. Space For Being True And Being Different B. An Opportunity To Aim Higher Despite The Odds C.A Place Where We Do Things Together.The Study Recommended Considering The Emotional, Socio-Cultural And Psychological Dimensions Of Well-Being When Crafting Youth Camp Activities To Maximize Indigenous Youth's Engagement. Creating More Democratic Spaces Like Youth Camps For Indigenous Youth Are Helpful In Achieving Their Academic Aspirations, Develop Social Skills And Lessens Feelings Of Discrimination.
\end{abstract}

Key Words: Youth Camp, Academic Aspirations, Indigenous Youth, Social Inclusion, Well-Being

\section{Introduction}

The United Nations (UN), In Its 2009 "State Of The World's Indigenous People" Report (UN, 2009), Lamented That, On A Global Scale, Indigenous Students, By Comparison To Nonindigenous Students In The Same Countries, Are Suffering From Lower Enrolment Rates In Education, Higher Dropout Rates And Poorer Educational Outcomes, And That A Majority Of Indigenous Children Do Not Have Access To Education That Is Specifically Designed For Their Needs, Taught In Their Languages Or That Reflects Their World Views. As A Result, Local And Global Responses From Educational Organizations Which Seek To Address This Educational Disparity Experienced By Indigenous Youth In Various Countries Are Well-Documented. Culturally Responsive Schooling (CRS), The Indigenization Of Education, Enabling Programs, Cultural Safety Circles, Youth Camp Initiatives And Other Educational Interventions Aimed At Improving School Retention, Academic Performance And Social, Cultural And Emotional Well-Being Among Indigenous Students Are Being Implemented (Gallop \&Bastien, 2016; Harwood Et Al, 2015; Martin \&Seguire, 2013; Price \&Mencke, 2013).

As Cited In The Arctic Centre Website, The Definition Of "Indigenous Peoples" In Article 1 (1b) Of The International Labourorganisation's Convention Concerning Indigenous And Tribal Peoples (ILO No. 169 ) Is "People In Independent Countries Who Are Regarded As Indigenous On Account Of Their Descent From The Populations Which Inhabited The Country, Or A Geographical Region To Which The Country Belongs, At The Time Of Conquest Or Colonisation Or The Establishment Of Present State Boundaries And Who, Irrespective Of Their Legal Status, Retain Some Or All Of Their Own Social, Economic, Cultural And Political Institutions" (N.D.). Moreover, The People's Self-Identification As Being Indigenous Or Tribal Is Essential For Them To Be Treated And Identified As Such.In The Philippines, Which Is Home To Around 110 Indigenous People's Communities Located In Different Parts Of The Country, Including The Igorotsin The Cordilleras Ofnorthern Luzon, The Aetas Or Negritos In Central Luzon, The Mangyans Of Mindoro, And Badjaos In Mindanao,A Consolidated Report By The Episcopal Commission On Indigenous People (ECIP)Revealed That School Serves As A Venue Where Various Dimensions Of Discrimination Against Indigenous People Are Perpetuated. The Marginalization Of Indigenous People Is Apparent In Educational Institutions Where Opportunities For Indigenous Youth To Be Educated Tend To Be Limited. Poverty, Of Course, Is A Major Stumbling Block That Limits People's Access To Education. 
However, The Marginalization Of Indigenous Youth In The Educational Setting Can Be Traced To The Enduring Institutionalization Of Racism Built Within The School Curriculum, The School Environment And Mainstream Society Where It Brings The "Alienation Of Indigenous Youth From Their Own Communities, Heritage, Culture And History" (ECIP, 2008, P. 116). Indigenous Youth Are Subjected To Racial Stereotypes That Perpetuate Their Image As Being Unschooled, Uncouth And Alienated Even From Their Peers. One Of The Better-Known Indigenous Groups In The Philippines Is The Aeta (Pronounced As "Eye-Ta,"), Believed To Be The Earliest Settlers In The Country.Numbering Anywhere Between 20,000 And 30,000, Aetas, Agta Or Aytaare Found Mostly In Central, Eastern And Southeastern Luzon As Well As In Some Parts Of The Islands Of Visayas. In Central Luzon, Aeta Communities Are Found In The Provinces Of Zambales, Pampanga, Tarlac And Bataan.In The Province Of Pampanga, Aeta Communities Are Found In The Uphill Areas Of Angeles City, Porac, And Mabalacat Municipalities. In 1991, Aetas Have Had To Cope With The Hazard Brought By The Eruption Of Mt. Pinatubo In Zambales Resulting In Their Physical, Socio-Cultural And Economic Dislocation. Although Aetas Were Originally A Nomadic People, Agriculture, Commercialization And Lowlander Settlements Greatly Limited Their Access To Foraging And Hunting Locations.The Mt. Pinatubo Eruption Displaced Them Further As The Area Around The Volcano Became Uninhabitable, And Many Of Them Had To Be Taken To Evacuation Centers In The Lowlands. This Natural Calamity Pushed The Aetas To Come In Contact With The Lifestyle And Economic Activities Of The Lowland People Of Central Luzon (Gaillard Et Al, 2007; Seitz, 1998). Providing Formal Education Was One Of The Programs (Alongside Access To Health Program Services) That The Philippine Government Has Provided To The Displaced Aetas As Part Of Its Post-Disaster Rehabilitation Policy. Prior To The Eruption Of Mt. Pinatubo, Aeta Access To Education Was Severely Limited As Very Few Schools Were Established In Remote Locations Where They Were Scattered And Settled In Groups. Some Groups Also Remained Mobile, Moving From Place To Place. Only Those Who Lived And Settled Near Villages Had Access To Schooling In Public Schoolfacilities. This Experienceof Mainstream Education Opened More Educational Opportunities For Aetas In Pampanga And Has, Over The Years, Realized The Benefits And Advantages An Education Can Bring To Them. This Has Also Encouraged Educational Institutions In Pampanga To Come Up With Various Outreach Opportunities To Help Aetas Succeed In Their Schooling Utilizingacademic And/Or NonAcademic Interventions. Holy Angel University (HAU), A Higher Education Institution Located In Angeles City In The Province Of Pampanga,Philippines Took Up The Challenge Of Supporting Indigenous Aeta College Students'academic Goalsby Organizing A Youth Camp Program Launched In The Summer Of 2015. The Goal Of The Youth Camp Was To Help Aeta College Students Cope With The Academic Rigors Of College Life, Develop Self-Confidence And Resilience, Bring About A Sense Of Pride In Their Indigenous Roots, And Improve Their Communication And Socialization Skills.The Youth Camp Orsummer Camp Is A Supervised Program For Children And Adolescents Whichis Usually Conducted During The Summer Months, And Lasts Anywhere Between Last Week Of May And First Week Of June. The Benefits For Young People Gained From Participating In Summer Youth Camps Are Well-Researched (Garst Et Al, 2011). Research Studies Suggest That It Can Develop Social Skills (Feenstra, 2015), Can Aid Student Retention, Student Resiliency And Academic And Socio-Emotional Development (Price \&Mencke, 2013) And Can Even Improve High School Students' Attitude And Approach Towards Subjects Such As Mathematics (Can Et Al, 2017).

Halsall, Et Al (2016) In Their Study Entitled, "Facilitating Positive Youth Development Through Residential Camp: Exploring Perceived Characteristics Of Effective Camp Counsellors And Strategies For Youth Engagement" Recommended The Following Strategies To Maximize Youth Engagement During Summer Camps: 1. Individualizing The Activities 2. Facilitating Initial Engagement By Making It Fun 3. Creating An AutonomySupportive Environment And 4.Providing Leadership Opportunities.

In 2015, The Pamimilamu Summer Aeta Youth Camp Outreach Program Emerged From An Initiative Of The Holy Angel University College Of Arts, Sciences And Education (HAU-Cased) Faculty And Student Volunteers, Working In Partnership With The Social Action Center Of Pampanga (SACOP), The Outreach/Community Development Arm Of The Catholic Archdiocese Of Pampanga. In 2015, SACOP Requested HAU-Cased To Provide Academic And Non-Academic Support To Aeta Students As Aeta College Students Were, Based On School Records, Widely Acknowledged To Be Struggling To Understand Lessons And Pass Exams In English And Mathematics. 


\subsection{Youth Camp Site: The Aetahanan Dormitory}

The Site Is Located In The Municipality Of Sta. Rita, Pampanga, South Of Angeles City [See Map Below]. Theaetahanan Dormitory Was Established And Is Being Run By SACOP. This Dormitory Was Established To Provide For The Housing Needs Of Aeta Youth Whose Families Live Far Away From Their School.Accommodation In Theaetahanan Dormitory Is Offered Free To Aeta Youth In Pampanga Who Are Enrolled As College Students In Their School Of Choice?. Though There Are Donors Who Provide These Students With Rice Subsidies And Other Food Commodities To Augment Their Daily Needs While Living In The Dormitory, These Aeta College Students Are Required To Provide For Their Own Personal Necessities. SACOP Presupposes That By Being In The Dormitory Near Their School Sites And Away From Their Respective Families And Responsibilities, These Aeta Teenagers Can Focus More On Their College Studies, With The Intent That Thisultimately Leads To The Successful Completion Of Their Tertiary Academic Degree Requirements.

\section{Statement of The Problem}

To Determine The Efficacy Of The Program, Especially As Thepamimilamuyouth Camp Program Reached Its Fourth Year Of Implementationlastmay Of 2018, An Evaluation Of The Effectiveness Of The Program Through The Retrospective Review Of Feedback Taken From Participants And Other Source Materials Was Conductedspecifically Toascertain Whether Its Objectiveshave Been Achieved Through The Program's Targeted Beneficiaries. Using Qualitative Approaches Anddescriptive Methods, This Study Evaluates The Extent To Which Thepamimilamu Youth Camp Outreach Program Experience Has Supported The Academic Attainment Of The Aeta Youth Camp Participants Over The Previous Four Years, As Well As Exploresitscontribution To Their Overall Well-Being And Sense Of Belonging As Defined By The Aeta Participants Themselves. Specifically, This Study Sought To Find Answers To The Following Research Questions:

1.How Best May The Pamimilamu Youth Camp Be Described In Terms Of Its Program And Activities?

2.What Are The Youth Camp Participants' Reflections In Attending Pamimilamu Youth Camp Vis-À-Vis Its Effects To Their College Studies?

3.How Do The Aeta Student Participants Perceive Of The Pamimilamu Youth Camp In Terms Of Its Contribution To Their Well-Being?

\section{Method}

\subsection{Research Design}

A Qualitative Descriptive Research Design Was Used In This Study, Describing What Exists That May Help To Uncover New Facts And Meaning. The Purpose Of Descriptive Research Is To Observe, Describe, And Document Aspects Of A Situation As It Naturally Occurs (Polit\&Hungler, 1999).

\subsection{Participants}

Majority Of The Youth Camp Participants Are Female With Age Ranges From 17-20 Years Of Age.Thirty-One Out Of 33youth Camp Participantstook Part In Evaluatingthe Pamimilamu Youth Camp Organized In 2015, 2016 And 2017 By Filling Up The Evaluation Formprovided By The HAU-OCES. Of The Thirty-Three, Ten (10) Were Invited To Participate Either In The Focus Group Discussions (FGD) Or Individual Interviews.

\subsection{Instruments}

Aside From Documentary Dataprovided By The HAU Office For Community Extension Services (HAU-OCES), Two Instruments Were Utilized For This Study To Obtain Primary Data: Validated Self-Made Interview Guide Used During The Focus Group Discussion And Individual Interviewsand The Evaluation Survey Questionnaire Provided By HAU-OCES.

\subsection{Data Collection}

For Research Question Number 1(How Best May The Pamimilamu Youth Camp Be Described In Terms Of Its Program And Activities?), Data Were Obtained From The Following:

1. Pamimilamu Youth Camp 2015, 2016, 2017\& 2018 Official Documents Such As Reports, Photos As Provided By The HAU-OCES

2. Informal Conversations With The Youth Camp Organizers And Student Volunteers

For Research Question Numbers 2(What Are The Youth Camp Participants' Reflections In Attending Pamimilamu Youth Camp Vis-À-Vis Its Effects To Their College Studies?)And 3(How Do The Aeta Student 
Participants Perceive Of The Pamimilamu Youth Camp In Terms Of Its Contribution To Their Well-Being?), Data Were Obtained From The Following:

1. Transcripts From Focus Group Discussions (FGD)

2. Accomplished Youth Camp Information Sheets

3. Accomplished Youth Camp Evaluation Forms

4. Youth Camp Participants' Journals

3.5 Ethical Consideration

As Part Of The Ethical Protocols, Informed Consent Was Secured From The Participants Who Took Part In This Study As Well As From The National Commission On Indigenous People (NCIP) In Compliance With NCIP's Administrative Order No. 1 Series Of 2012 Otherwise Known As The Indigenous Knowledge Systems And Practices (Iksps) And Customary Laws (Cls) Research And Documentation Guidelines Of 2012.More So, Confidentiality And Anonymity Were Strictly Practiced Throughout The Study.

\subsection{Data Analysis}

For The Transcribed Focus Group Discussions Interview, Data Analysis Began With A Thorough Reading And Re-Reading Of Each Transcript Line By Line And Sentence By Sentence. After Which, The Transcriptsweretranslated From Kapampangan (The Native Language In Pampanga) Into English And Analyzed Using The Grounded Theory Method (GTM) Coding Techniques As Described By Strauss And Corbin (Cited In Bailey, 2007; Creswell, 2007 And Flick, 2006). The Data Analysis Process Proceeded Through Three Phases Of Coding: Open, Axial And Selective. In The Initial Process Of Open Coding, General Categories Were Identified By Segmenting, Characterizing And Summarizing Data By A Word Or A Phrase. As Soon As General Categories Wereunraveled, An Axial Coding Process Followed Wherein General Categories Were Further Grouped And Categorized Until A Core Category And Sub-Categories Emerged From The Data. In The Selective Coding Process, Constant Comparison And Examination Of Data And The Relationship Of Categories Were Made. For The Completed Evaluation Survey Questionnaire, Percentage And Mean Were Computedwith Corresponding Interpretation.

\section{Findings}

To Answer The First Research Question, I.E. How Best May The Pamimilamu Youth Camp Be Described In Terms Of Its Program And Activities?, This Section Begins With A Description Of Therationale Of The Pamimilamuyouth Camp Program As Well As Its Curriculum And Activities Which Were Conceptualized And Implemented In The Past Four Youth Camps (I.E. 2015, 2016, 2017, 2018). The Second Part, For The Second And Third Research Questions, Presents The Youth Camp Participants' Realizations Reflections?And Insights Arranged Thematically Based On The Evaluations, Narratives, Observations And Reflections By The Aeta Youth Camp Participants.

\subsection{The Pamimilamu Aeta Youth Camp Program}

Dubbed As Pamimilamu (An Aeta Word For Solidarity) Youth Camp Program, This Is A Live-In Camp Activity With A Duration Of Three To Five Days Whose Objectives Are Two-Pronged: To Promote Understanding, Fellowship And Solidarity Within And Among The Aeta Youth Participants And HAU Volunteers And To Provide Experiences Which Benefit The Camp Participants' Holistic Well-Being Whilst Helping Them With Their College Studies. Undertaking A Youth Camp Was Thought Of By Both Parties As An Entry Point Towards Achieving The Camp's Objective. Both Parties Agreed That The Youth Camp Was To Be Held At Aetahanan Dormitory In Brgy. Dila-Dila, Sta. Rita, Pampanga. The Decision To Use The Dormitory As The Camp Venue Was Also A Way To (Hopefully) Create Lasting Positive Memories That The Aeta College Students Would Associate With Their Residence At Theaetahanandormitory.

For Four Consecutive Years, The Youth Camp Was Scheduled To Take Place Over The Last Two Days Of May And First Two Days Of June As These Days Were The Only Option For The Organizers. The Aeta College Students Usually Go Home At The End Of The School Year (Usually At The End Of March) And Help Their Respective Families By Taking Summer Jobs During The Months Of April And May Or Until Before Their Next School Semester Begins In The Month Of June. The Money They Earned From These Summer Jobs Becomes Their Financial Resources To Augment Their Personal Expenses Once They Return To School. 


\subsection{Camp Activities}

The First Pamimilamu Youth Camp Program, With The Theme Statedin Filipino As Ikaw, Ako, Tayo Para Sa Samahang May Forever"'(You, Me And All Of Us For A Fellowship That Lasts Forever) Was Held In May 2015 (See Appendix A). Three Skills-Based Workshops Were Conducted In The Morning And Afternoon Sessions: A Workshop On Public Speaking, Paper Letter-Cutting And Bonsai Plant-Making. Teambuilding Activities In The Form Of Relay Games Were Also Held In The Early Morning And Mid-Afternoon. Two Teamscomprising Of Five To Six Memberswere Pitted Against Each Other In The Spirit Of Friendly Competition As They Competed To Win Each Game. After Each Relay Game, Discussions Were Facilitated As To The Purposes Of The Relay Game And What It Was Intended To Convey To Camp Participants (E.G. Collaborative Working). The Relay Games Were Reported To Be Physically Exhausting But At The Same Time Enjoyable By All Participants. Late Afternoon And Early Evening Sessionswhich Lasted For Three To Four Hourswere Devoted To Sharing Stories And Small Group Discussions.Throughout The Youth Camp Days, Group Singing And Prayingwere The Culmination Of Each Night Before Bedtime And Also At The Start Of Each Day Before New Activities Began. All Of The Aeta Students Are Members Of The Catholic Church. During The Second Pamimilamu Youth Camp Program Held In May 2016, The Theme Of The Event Was\#Boses Ng Kabataang Aeta, Boses Ng Pag-Asa (The Voice Of The Aeta Youth, The Voice Of Hope). The Duration Of The Youth Camp Was Expanded From Three To Four Days To Accommodate Three New Activitiesinaddition To Community Singing, Praying And Teambuilding Activities Similar To Those Undertaken In The Previous Year. The Third Workshop (In 2017) Was About Indigenous People's Human Rights. The Workshop Began With An Activity That Asked Each Group (Consisting Of Three To Four Members) To Answer Two Questions: What Are The Important Qualities Or Characteristics That Make Us Human? What Do We Need To Do To Ensure That These Qualities Are Protected Or Preserved? Participants Discussed And Wrote Their Answers On A Human Figure Drawing On A Piece Ofmanila Paper.

A Synthesis Of All These Inputs Was Produced And Ideas Were Integratedinto A.... The Participants Were Then Led Into A Discussion On Human Dignity And How Upholding Human Rights Protect One's Human Dignity. Indigenous People's Rights Were Then Explained One By One. Unlike In The Previous Pamimilamu Aeta Youth Camp Where The Last Day Of The Event Had Consisted Of Community Singing And Awarding Of Certificates To Both Camp Participants And HAU-Cased Volunteers, The Second Youth Camp's (2016) Culminating Activity Also Gave The Camp Participants The Opportunity To Give Performances Of The Productions They Had Practiced In Their Speech And Contemporary Dance Workshops. For The Third And Fourth Pamimilamu Youth Camp, It Carried The Same Theme From 2016. The Same Set Of Workshops Was Given To The Participants: Specifically On Public Speaking And Dance Interpretation Workshops. Performances By The Camp Participants Were Then Rehearsed To Be Given As Their Culminating Production Number At The End Of The Youth Camp. In Addition, Two New Activities Designed To Elicit Reflectionsregarding...From The Participants Were Organized: The First Was A Follow-Up Lecture On Indigenous Rights Given To The Youth Camp Participants But This Time, It Focused On The Right Of Indigenous People To Quality Education. The Second Activity Was A Group 'Sharing' Which Immediately Followed The Lecture. Learning From The Previous Two Youth Camps, During Which The Bonfire Was Built Within One Big Circle, This Time Smaller Circles Of Group Sharing Over Separate Bonfires Were Set Up To Ensure That Every Participant Would Have Enough Time To Share Their Thoughts. The Second One Was Called, "Celebration Of Light" Where Participants Used Lighted Candles To Symbolize Being A Light For Others.

\subsection{Youth Camp Participants' Realizations And Insights}

Overall, The Majority Of The Camp Participants Rated Their Camp Experience As Either Very Useful Or Excellent (Overall Rating $=3.72 / 4.00$ ). Table 1 Below Shows The Summary Of The Averages For Each Component Of The Youth Camp .The Majority Of The Participants Cited'Learning A Lot' As The Most Popular Element Of T Heir Experience Of Attending The Pamimilamu Youth Camp Followed By 'Experiencing Unity And Cooperation'. Table 2 Summarizes What The Participants Liked Best About The Youth Camp.

Further Analysis Of The Pamimilamuyouth Camp Participants'qualitative Responses From The Survey's OpenEnded Questions, Focus Group Discussion (FGD) And Individual Interviews Conducted Yieldedthreesignificant Themes:

a.A Space For Being True And Being Different

b.An Opportunity To Aim Higher Despite The Odds

c.A Place Where We Do Things Together 
a. A Space For Being True And Being Different

Space Is Defined Not Only In Its Physical Aspects But Also More Importantly In Relation To The Meaning It Implies To Individuals Using Those Spaces (Sanchez Et Al, 2015). For The Camp Participants, Pamimilamuis A Space Where It Allowedthem To Openly Express Their Thoughts And Feelings Regarding.... Whether In Small Circles Of Sharing Or During Group Activities, It Made Them Feel At Ease In Expressing Themselves Without The Fear Of Being Ridiculed Or Taken Less Seriously. The Narratives Of The Youth Camp Participants Revolved Around Their Need To Belongto Mainstream Filipino Societyand To Be Accepted Not Just By Their Fellow Aetas But Especially By Non-Aetas. This Is What They Believe People From Outside Their Community (I.E. Non-Aetas) Should Be Giving Theminstead Of Being Subjected To Discrimination And Exclusion. Being Integrated In The Mainstream Society Is Seen As A Necessity For Them. As One Female Participant Put It(Translated From The Kapampangan Language Into English):

\section{Just Because You're With A Fellow Aeta It Doesn't Mean That It's Only The Two \\ Of You That's Together Everywhere You Go.}

From The Small Group Discussions And Sharing Of Stories With The Camp Participants, The Strongly Recurring Theme Throughout Indigenous Participants' Narratives Are Of Discrimination That They Have Experienced In Theirschooling Especially During Their High School Years. For Example, They Reported Beingbullied Or Labeledas... By Their Non-Aeta Classmatesbecause Of Their Distinct Physical Features. They Were Often Teased Or Labeledas "Baluga" Which Is A Derogatory Term For Individuals With Dark Complexion Or "Kulot", A Term Denoting Someone With Short Kinky Hair. They Rejected Use Of These Terms Which They Experienced As Discriminatory And Wanted To Be Referredto Or Called As "Kapatads" (The Kapampangan Term For Kapatid Which Means Sibling) Or Simplyaeta. Aside From Discrimination And Verbal Discrimination Focused On Their Looks, Indigenous Camp Participants Narratedthatsome Peopleappeared To Think Of Their Academic Ability Or Capability, Their Manner Of Dressing And Lifestyle As Inferiorto That Of The Mainstream Population, And Thus, Provided An Excusefor Aetas To Be Ridiculed In School Especially When Speaking In English, Which Is One Of The Official Languages In The Philippines, Second To Filipino. One Camp Participant Recalledher Experience Inside Herclass. Her Classmates Made Fun Of Her Whenever She Spoke In English Or Wroteessays Ungrammatically,Both Skills She Admittedwere Things Which Sheconstantly Had Difficulty With. Another Youth Camp Participant Spoke Of Her Experiences Of Being Excluded In Group Discussions Inside The Class With Remarks From Her Non-Aeta Classmates Such As "Ayaw Naming Silangkasama" (We Do Not Want Them To Be Part Of The Group), "Walangmaitutulong" (Cannot Contribute Anything) Or "Walangalam" (Knows Nothing). One Of The Youth Camp Participantsshared Her Frustration (Her Statement Below Is Translated From Kapampangan Into English):

We Are All Human Beings. I Do Not Know Why They Treat Us Like That.

However, Some Participants Shared That Not All Of Their Non-Aeta Classmates Are Unfriendly. One Female Participant, Citing An Instance, Recalled:

It's Like When We Don't Have Money, When We Have Fees To Pay In School...Ah, They're The Ones Who Like Give...Like "It's Okay, I'll Pay For You

For Now. When You Have Money, You Just Pay Me Back". There, That's Their

Help To Us. Then Sometimes, They Let Us Copy Their Assignments.

The Majority Of The Aeta Participants In The Camps Are "Irregular Students." To Be An Irregular Student Means To Not Have The Same Set Of Class Schedules As Their Non-Aeta Peers. This Situation Is Thought Of As Contributoryto Them Experiencing Being Separated From, Orhaving Less Interaction With Their Fellow Aetas And Hence Perceived Of As Not Helping With Their Integration. As One Participant Shared:

We're Irregular Students... Sometimes I'm All Alone In School So When...Yes, Like What They Say, Let Yourself Get Used To Having...No Other Fellow Aeta.

Then You Let Yourself Get Used To It But Having Someone Else Is Still Better.

The Sharing Of Experiences During The Youth Camp Led Participants To Developimportant Realizations. Among These Were Realizations Of The Processes And Challenges Of Coping With Discrimination. Some Students Werehowever More Determined To Learn How Not To Mind, Or To Overcome Discriminatory Treatment. During The Small Group Discussions One Camp Participantsaid: 
Whether We Like It Or Not, There Will Still Be People Who Will Discriminate Us

Because We Are Kinky-Haired. It Is Really Up To Us How We Are Going To

Defend Ourselves. If We Always Allow Ourselves To Be Taken Advantage By Others Nothing Good Will Happen. We Need To Trust Our Own Capabilities And Trust The Lord God.

b. An Opportunity To Aim Higher Despite The Odds

Aspirations Are Defined As One's Hopes And Dreams. They Connote A Person's Idea Of A “Good Life" And How He Or She Can Achieve This Given The Available Material And Non-Material Resources He Or She Has At The Moment (Conradie, 2013). Despite Their Academic Difficulties, Camp Participants' Expressed A Determination To Learn And Finish Schooling, Motivating Them To Participate In The Tutorials And Workshops Offered By The Pamimilamu Youth Camp. For The Camp Participants, Attending The Pamimilamu Youth Camp Was Seen As Preparing Them Academically For The Opening Of Classes When The Next Semester Began In June. "It Will No Longer Overwhelm Your Brain"Was How One Participant Described It. Through The Various Lessonsthey Took Part In During The Youth Camp:- For Example, Enhancing Their Public Speaking, Use Of Correct Grammar, Pronunciation And Vocabulary, Their Stock Of Knowledge(Which Might Have Been Diminished During Time Away From An Academic Environment With Their Families) Was Refreshed. Participants Claimed To Be More Attentive In Listening To Their Teachers' Discussionswhen Back In Class, As A Result Of Their Regular Participation In The Youth Camp Sessions. More So, It Was Also Reported As Helping Them Overcome Their Shyness Especially Whenspeaking The English Language In Front Of The Class. One Participant, Realizing That Dealing With Non-Aetas Is Something That Cannot Be Avoided In Their Academic Life, Shared That They Appreciated The Opportunities To Develop Public Speaking Skills As :

\section{Because As An Aeta, We Are Too Shy, Like Ah, I Need To Overcome My Shyness. I Needed To Face Them As A Person, Like That.}

The Contribution Of Volunteer Camp Facilitators And Staff In The Camp Setting Was Favorably Acknowledged By The Participants As Contributory To Their Development Of Desirable Social Skills(Halsall, Kendellen, \&Forneris, 2016). The Active Participation Of Student Volunteers From HAU (Who Are Non-Aetas)Is Considered Significant By The Camp Participants And Serves As Encouragement For The Latter To Pursue Their Own College Studies And Continue Attending The Pamimilamu Youth Camp.

c.A Place Where We Do Things Together

It Has Been Acknowledged That Summer Camps Can Have An Impact On The Development Of The Camp Participants' Social Skills (Shirilla, \&Gass, 2008). This Include Elements Of Social Skills Such As Theability To Cooperate And Interact With Peers: Two Of The Most Recurrent Themes Generated From The Participants' Responsescollected Through.... The Pamimilamu Youth Camp,Thus,Served As An Opportunity For Aeta Participants To Develop A Sense Of Unity And Belongingness, Both Between And Among Themselves, As Well Aswith The HAU Student Volunteers. Teambuilding Exercises Such As... Were Considered Fun And Enjoyable By The Camp Participants And Were Reported To Fostera Sense Of Belongingness Between And Among The Aeta Camp Participants And The Student Volunteer Facilitators. One Aeta Participant, Recalling The Teambuilding Exercise Where Each Group Was Tasked To Build A Durable Tower Using Only Plastic Straws, Compared The Experience With Their Unity With The Aetas As Like Straws Bundled Together,

"That No Matter What Challenges Come By Us, We Won't...Become...We'll Become Strong."

Student Participants Experienced The Spirit Of Belongingnessnot Only During Structured Workshop Sessions, But Also During Session Breaks Such As Meal Times. As One Female Participant Shared:

\section{Those When We're Together, When We're Eating ..During The Games...In The Groups. Of Course, You Bring That With You Until You Grow Older Because When You Age, It's Like, It's Like You Miss Being...}

However, Aeta Participants Confessed That There Were Also Awkward Moments At The Start Of The Youth Camp. For Them, Mingling With Their Non-Aetacamp Volunteers From HAU (Calling Them As Ate[Older Sister] Or Kuya[Older Brother]) During The Youth Camp Helped Them In Adjusting To Their Real College Environment Where Their Class Mates Are Predominantly Non-Aetas. The Pamimilamu Youth Camp Thus 
Allowed Them To Become Closer With Student Volunteers Whom They Feel Accepted Them For Who They Are. One Aetacamp Participant Shared In Her Reflection Journal:

To End My Reflection Regarding Our Relationship To The Organizers They Made Us Feel That They Accepted Us For Who We Are, Loved Us For What We Have And Made Us Happy By Organizing A Summer Camp That Empower Us To Create Our Own Version Of Our Self That Can Help Us To Be A Productive Individuals.

On The Last Day Of The Youth Camp, One Of The HAU Volunteer Student Facilitators Was Surprised By The Remarks Of One Of The Aeta Camp Participants. He Said:

During Our Last Day, One Of Them Said, "Kuya, I Hope, You Won't Change In The Way You Treat Us." I Replied With A Nod And Said "No, I Won't Change." During That Moment I've Felt Their Longing To Be Accepted The Way Other People Long To Be Accepted, And I Know For A Fact That That Would Change Because They Are Hardworking, Courageous, But Most Of All, They Are

Determined. And That Can Change The Way People Think About Them.

During The Pamimilamu Youth Camp Program, The Immediate Academic And Non-Academic Needs Of The Camp Participants Were Identified Through A Variety Of Formal And Informal Channels Of Communication. As Such, HAU School Of Arts \& Sciences (SAS) And School Of Education (Sed) Faculty And Student Volunteers Were Able To Organize Follow-Up Activities For These Youth Camp Participants During The Academic Year Or Between Pamimilamu Youth Camps. The Activities Which Were Arranged Are As Follows:

1.Free Government-Mandated Board Exam Review Class - After The Second And Third Pamimilamu Youth Camp, Free Formal Board Examination Review Classes Were Offered To Aeta Camp Participants Who Were Graduates Of Teacher Education Courses. This Type Of Review Is Critical To Them Passing The Licensure Board Examinations For Teachers. These Were Provided In Preparation For Their Licensure Examination For Teachers (LET)Held Every Month Of September. The Review Classes Were Provided By The HAU School Of Education From May To Septemberin Both 2016 And 2017 At HAU;

2.Tutorial Sessions - After The Second Pamimilamu Youth Camp, It Was Agreedamong...To Provide Tutorial Sessions For Aeta Camp Participants Who Were Having Difficulties With Their English, Academic Thesis And Math Lessons. These Were Organized And Conducted By Volunteer English And Research Professors And Engineering Studentswho Were Assumed To Encounter Very Little Difficulty In Imparting Knowledge They Were Well-Versed In. These Tutorial Sessions Were Held Either At The Aetahanan Dormitory Or At HAU Library; And Life Skills Seminar-Workshop - After The Third Pamimilamu Youth Camp,Life Skills Seminars And Workshops Facilitated By Volunteer Psychology Professors And Students From The HAU School Of Arts And Sciences Were Provided.

\section{Discussion}

This Study Sought To Evaluate Whether The Objectives Of The Pamimilamu Aeta Summer Youth Camp Outreach Program Have Been Achieved By Its Intended Beneficiaries. Using A Qualitative Descriptive Approach, The Study Revealed That Aeta College Students' Participation In The Pamimilamu Summer Camp Provided Them The Followingexperiences: A Space Where Their Experiences Of Exclusion Or Discrimination In Educational Settings Were Able To Befreely Shared With Their Fellow Aeta Participants As Well As A Space To Discuss Their Aspirations For Academic Achievement And An Opportunity To Enjoy The Companionship Of Their Peers, Both Aeta And Non-Aeta.The Findings On The Existence Of Discrimination And Exclusion Experienced By Indigenous Youth Such As The Aetas In Mainstream Educational Settings Were In Agreement With The Previous Research Conclusions On This Subject (E.G. ECIP, 2008; Hare \& Pidgeon, 2011; Khanlou, Koh, \& Mill, 2008). Price And Mencke's (2013)Four Dimensions Of Well-Being To Be Considered When Crafting Camp Curriculum And Activities For Indigenous Youth To Provide A Culturally Responsive Youth Camp Became Road Map For The Camp Organizers. These Four Dimensions Of Well-Being Are Social WellBeing, Emotional Well-Being, Cultural Well-Being And Psychological Well-Being. Social Well-Being Encompasses Connection With Family, Peers, School And Community. Emotional Well-Being Includes The Ability To Cope And Deal With, Among Other Things, Discrimination And Racism. 
Cultural Well-Being Refers To The Ability To Live And Survive In Two Worlds, Knowledge Of History, Positive Identity And Connection To The Cultural Community. And Lastly, Psychological Well-Being Describes One's Positive Sense Of Self, Social Adjustment, Knowledge Of Drug And Alcohol Misuse.Thepamimilamu Summer Youth Camp Provided A Space For Theindigenous Aeta Camp Participants Who, Through Small Circles Of Sharing And Other Group-Based Tasks, Have Verbally And Non-Verbally Articulatedfreely Their Personal Experiences Of Struggling With Discrimination From Their Non-Aeta Peers In And Out Of Their School Environment.

The Pamimilamu Youth Camp Curriculum Was Designed To Empower Indigenous Aeta Students By Allowing Them To Confront The Oppression They Are Experiencing, Even Those That Happen Within School Environment. This Is Attributed To The Nature Of Pamimilamu Camp Activities Which Were Organizedaround The Importance Of Social, Emotional, Cultural And Psychological Well-Being Of The Indigenous Youth. Pamimilamu Youth Camp Utilized Paulo Freire's Method Of The Use Of Problem-Posing Approach (Consciousness-Raising Through Critical Thinking) Over Banking Approach (Transmitting Knowledge Through Rote Learning) To Empower Students In View Of Changing Their Current Situation (Freire, 2005). As Price Andmencke $(2013,91)$, Organizers Of Summer Camps To Indigenous Native American Youths, Succinctly Concluded In Their Study That, "When Students Are Provided A Space To Express, Critique, And Build Relationships, They Become Engaged In Their Own Learning."

\section{Conclusion}

Anthropologist Arjun Appadurai Introduced The Notion Of Expanding Aspirational Capacity Among Socially And Economically Marginalized Sectors Of Societies To Increase Their Capabilities Thereby Improving Their Exercise Of Choice And Agency (Cited In Prodonovich Et Al, 2014 \&Zipin Et Al, 2015). This Implies That The Aspirational Capacity Of Marginalized Sections Of Society Such As The Indigenous People Must Be Enhanced Through Intervention Activities. This Study Argued That Aeta Camp Participants Struggle With Their Aspiration To Fulfill Their Academic Requirementsdue To Societal And Educational Constraints. Pamimilamu Aeta Summer Youth Camp Acted As Anintervention Toexpandtheircapacity To Aspire For More. Through Their Active Participation In The Pamimilamu Camp, The Aeta Young People Engaged And Heightened Their Understanding Of Their Own Marginalization (I.E. Discrimination In School). Through Reflecting And Sharing Stories, They Were Able To Clarify How They See Themselves In Contrast With How Others See Them. Aeta Camp Participants Also Realized That They Draw Sources Of Support From Their Families, Fellow Aetas And Their Christian Faith As Their Way Of Coping And Resisting The Discrimination And Hostilities In School (Hare \& Pidgeon, 2011; Khanlou, Koh, \& Mill, 2008). These Reflections And Realizations Led Them And The Youth Camp Organizers Towardsconcrete Solutions(E.G. Life Skills Seminar-Workshop, Tutorials, Etc. As Detailed In The Final Part Of The Results Section) That Will Enhance Their Capabilitiesthereby Expanding Their Academic Aspiration. The Author Of Thisstudy Acknowledges A Number Of Limitations That Could Impact Its Present Findings And Could Provide Directions For Future Research. First, The Primaryyouth Organizer Of The Pamimilamu Youth Summer Camp Is Also The Key Researcher - A Situationthat Could Potentially Influence The Findingsas A Result Of Researcher Bias. While The Author Employed Member-Checking Of Presumptions And Findings, Where The Research Participants Served As The Researcher's Check Throughout The Analysis Process, This Itself Was Not Consistently Conducted As All Research Participants Have Been Unavailable Due To Various Reasons.Future Research Should Ensure Constant Dialogue Between The Researcher And The Research Participants Regarding The Former's Interpretations Of Their Experiences Detailed In Interview Data To Ensure Validity.However, The Author Captured Fully The Participants' Own Interpretation Of Their Experiences By Providing Thick Description In The Presentation Of Findings. Secondly, As This Study's Sample Consists Mostly Females,Numbering 20 Out Of 30from 2015 To 2018,Caution On The Generalizability Of The Findings Must Be Made As Gender Can Be Animportant Variable In Terms Of How Aeta Young People Deal And Cope With Academic Difficulties, Discrimination And Hostilities In School. In This Regard, Future Researchespertinent To This Phenomenon May Be Conducted Among Male Aeta College Students. And Lastly, Not All Participants In This Study Have Attended All Thethree Pamimilamu Youth Camps. The Unevenness Of The Frequency Of Their Attendance To The Youth Camp Could Also Have An Influence On Their Qualitative Responses During The Interview And Focus Group Discussions. For Future Research, The Frequency Of Camp Attendance By The Participants Must Be Given Serious Consideration. 
For Future Organizers Of Summer Camp For Indigenous Young People Like The Aetas, It Is Recommended That The Social, Cultural, Psychological And Emotional Dimensions Of Their Well-Being Must Be Always Considered In Crafting Camp Activities To Ensure Holistic And Meaningful Engagement (Gallop \&Bastien, 2016; Price \&Mencke, 2013).

Despite These Limitations, The Findings Of This Study Canserve As Aninvaluable Piece Of Empirical Evidence For Religious Non-Government Organizations (Ngos) Such As The Social Action Center Of Pampanga (SACOP) Of The Catholic Archdiocese Of Pampanga As The Above Organization Continues To Explore Culturally Relevant Ways Of Ministering To The Educational Needs Of The Aeta Youths In Pampanga, With A Particular Focus On Assisting Aeta Youth To Succeed In Their College Studies. Higher Education Institutions (Heis) Engaged In Empowering Indigenous Communities For Example The Holy Angel University Office For Community Extension Services (HAU-OCES), May Also Find The Recommendations And Results Of This Study Useful In Formulating Relevant And Culturally Sensitive Educational Support System (E.G. Academic Enabling Programs) For The Aeta Youth Pursuing Higher Education, As Well Asof Value In Continuously Improving Summer Youth Camps Customized For Aeta College Students With A View Of Providing Academic And Non-Academic Assistance Towards Their Achievement Of Academic Aspirations. As Evidenced Above, In The Light Of Socio-Cultural Marginalization Faced By Indigenous Peoples Like The Aetas, Engaging Indigenous College Students To Actively Participate In Youth Camps Such As The Pamimilamuhas The Potential To Favorably Impact On Aeta's Academic Aspirations, Develop Social Skills And Lessen Feelings Of Social Exclusion Through Closer Engagement With Non-Indigenous Peers. Furthemore, Higher Education Institutions (Heis) Working To Assist Indigenous Youth Beyond The Dole-Out Approach(I.E. Giving Or Distributing Resources Such As Food, School Supplies, Etc.), Could Also Harness The Above Discussion On The Value Of Youth Camps As An Effective Developmental Strategy In Promoting An Inclusive And Quality Education For Aeta And Other Indigenousyouth.

Table 1

\begin{tabular}{ccc}
\hline Youth Camp Component & Mean & Interpretation \\
\hline Content & $3.61 / 4.00$ & Useful \\
Session Length & $3.57 / 4.00$ & Useful \\
Facilitation Process & $3.79 / 4.00$ & Useful \\
Tutor & $3.76 / 4.00$ & Useful \\
Tutee & $3.69 / 4.00$ & Useful \\
Facilitators & $3.81 / 4.00$ & Useful \\
& & \\
\hline What Did You Like About & Table 2 & $(\boldsymbol{\%})$ \\
The Youth Camp & $\boldsymbol{F}$ & 38.70 \\
\hline Learned A Lot & 12 & 22.58 \\
Unity And Cooperation & 7 & 12.90 \\
Many Activities & 4 & 12.90 \\
Activities & 4 & 9.68 \\
Enjoyable Games And Group & 31 & 3.22 \\
Sharing And Meeting Friends & & 100 \\
No Response & $30 t a l$ &
\end{tabular}




\section{References}

Arctic Centre: University Of Lapland (Undated).Definition Of Indigenous Peoples.Retrieved From:Https://Www.Arcticcentre.Org/EN/Arcticregion/Arctic-Indigenous-Peoples/Definitions

Bailey, Carol A. (2007). A Guide To Qualitative Field Research Second Edition. Pine Forge Press: USA

Can, I., Koydemir, S., Durhan, S., Ogan, S., Gozukara, C., \&Cokluk, G. (2017).Changing High School Students' Attitudes Towards Mathematics In A Summer Camp: Happiness Matters.Educational Sciences: Theory \& Practice, 17(5), 1625-1648. Doi:10.12738/Estp.2017.5.0373

Creswell, John (2007). Qualitative Inquiry \& Research Design/Choosing Among |Five Approaches Second Edition. Sage Publications: USA

Conradie, I. (2013). Can Deliberate Efforts To Realise Aspirations Increase Capabilities? A South African Case Study.Oxford Development Studies, 41(2), 189-219. Doi:10.1080/13600818.2013.790949

Episcopal Commission On Indigenous People (2008). Indigenous People's Education: "From Alienation To Rootedness". Human Rights Education In Asian Schools. Retrieved From: Http://Www.Hurights.Or.Jp/Archives/Pdf/Asia-S-Ed/V11/13Indigenous\%20Peoples\%20Education\%20$\% 20$ Philippines.Pdf

Flick, Uwe (2006).An Introduction To Qualitative Research $3{ }^{\text {rd }}$ Edition. Sage Publications, Inc.: UK

Fomag-As, David, Et Al (Undated).Socio-Cultural And Political Significance Of Ethnocide To College Students Of Baguio City. Retrieved From:

Http://Mpspc.Tripod.Com/Sitebuildercontent/Sitebuilderfiles/Socioculturalandpoliticalsignificanceofethn ocidetocollegestudents of baguiocity.Pdf Date Retrieved: April 14, 2017

Feenstra, J. S. (2015). Summer Camp And Positive Youth Development: Program With Romanian Youth. Physical Educator, 72185-199.

Freire, Paulo (2005). Pedagogy Of The Oppressed (30 ${ }^{\text {th }}$ Anniversary Edition). The Continuum International Publishing Group Inc. USA

Gaillard, Jean-Christophe \& Masson, Virgnie Le (2007).Traditional Societies' Response To Volcanic Hazards In The Philippines.Mountain Research And Development 27 (4), 313. Retrieved From Proquest Central

Gallop, C. J., \&Bastien, N. (2016).Supporting Success: Aboriginal Students In Higher Education. The Canadian Journal of Higher Education, 46(2), 206-224. Retrieved From Https://Search.Proquest.Com/Docview/1824510902?Accountid=148769

Garst, Barry \& Browne, Laurie \&Bialeschki, M. (2011). Youth Development And The Camp Experience. New Directions For Youth Development. 2011. 73-87. 10.1002/Yd.398.

Halsall, T., Kendellen, K., Bean, C. N., \&Forneris, T. (2016). Facilitating Positive Youth Development Through Residential Camp: Exploring Perceived Characteristics Of Effective Camp Counsellors And Strategies For Youth Engagement. Journal Of Park \& Recreation Administration, 34(4), 20-35. Doi:10.18666/JPRA-2016-V34-I4-7273

Hare, J., \& Pidgeon, M. (2011). The Way Of The Warrior: Indigenous Youth Navigating The Challenges Of Schooling. Canadian Journal of Education, 34(2), 93-111. Retrieved From Https://Search.Proquest.Com/Docview/881643999?Accountid=148769

Harwood, V., Mcmahon, S., O'shea, S., Bodkin-Andrews, G., \& Priestly, A. (2015). Recognising Aspiration: The AIME Program's Effectiveness In Inspiring Indigenous Young People's Participation In Schooling And Opportunities For Further Education And Employment. Australian Educational Researcher, 42(2), 217236. Doi: Http://Dx.Doi.Org/10.1007/S13384-015-0174-3

Khanlou, N., Koh, J. G., \& Mill, C. (2008).Cultural Identity And Experiences Of Prejudice And Discrimination Of Afghan And Iranian Immigrant Youth.International Journal Of Mental Health And Addiction, 6(4), 494-513.

Martin, D., Phd.,\&Seguire, M., M.N. (2013). Creating A Path For Indigenous Student Success In Baccalaureate Nursing Education. Journal Of Nursing Education, 52(4), 205-209.

Doi: Http://Dx.Doi.Org/10.3928/01484834-20130314-01

Mencke, Paul D. \& Price, Paula Groves (2013). Critical Pedagogy And Praxis With Native American Youth: Cultivating Change Through Participatory Action Research. Education Foundation Studies, Summer-Fall. Retrieved From: Https://Eric.Ed.Gov/?Id=EJ1065661 
Neumann, J. W. (2013). Advocating For A More Effective Critical Pedagogy By Examining Structural Obstacles To Critical Educational Reform. The Urban Review, 45(5), 728-740.

Doi: Http://Dx.Doi.Org/10.1007/S11256-013-0244-7

Pidgeon, M. (2016). More Than A Checklist: Meaningful Indigenous Inclusion In Higher Education. Social Inclusion, 4(1) Doi: Http://Dx.Doi.Org/10.17645/Si.V4i1.436

Polit D.F., Hungler B.P. (1999). Nursing Research: Principles And Methods (6th Ed) Philadelphia, Lippincott.

Prodonovich, S., Perry, L. B. \& Taggart, A. (2014).Developing Conceptual Understandings Of The Capacity To Aspire For Higher Education.Issues In Educational Research, 24(2), 174-189.

Http://Www.Iier.Org.Au/Lier24/Prodonovich.Html

Rossingh, B. \& Dunbar, T. (2012).A Participative Evaluation Model To Refine Academic Support For First Year Indigenous Higher Education Students.The International Journal Of The First Year In Higher Education, 3(1). 61-74. Doi: Http://10.5204/Intjfyhe.V3i1.113

Sánchez Romero , M., AlarcónGarcía, E., \& Aranda Jiménez, G. (2015).Children, Spaces and Identity. Philadelphia: Oxbow Books.

Seitz, Stefan (1998). Coping Strategies In An Ethnic Minority Group: Theaeta of Mount Pinatubo.

Disasters.22(1). 76-90

Shirilla, P., \&Gass, M. (2008).An Evaluation Of The Impact Of A One-Week Summer Camp Experience On Participants' Social Skill Development.Research In Outdoor Education, 939-41.

United Nations (2008).United Nations Declaration on the Rights of Indigenous Peoples. Retrieved From: Http://Www.Un.Org/Esa/Socdev/Unpfii/Documents/DRIPS_En.Pdf

United Nations (2009).State Of the World's Indigenous People. Retrieved From: Http://Www.Un.Org/Esa/Socdev/Unpfii/Documents/SOWIP/En/SOWIP_Web.Pdf

Victor, Marie Lourie And Yano, Belmer. Actualizing The Inclusion Of Indigenous Peoples' Rights In Education: A Policy Initiative In The Philippines (Undated). Retrieved From:

Http://Www.Hurights.Or.Jp/Archives/Asia-

Pacific/Section1/9\%20Indigenous\%20Peoples\%E2\%80\%99\%20Rights\%20in\%20Education.Pdf Date Retrieved: April 14, 2017

Zipin, L., Sellar, S., Brennan, M., \& Gale, T. (2015).Educating For Futures In Marginalized Regions: A Sociological Framework For Rethinking And Researching Aspirations.Educational Philosophy \& Theory, 47(3), 227-246. Doi:10.1080/00131857.2013.839376 